\title{
Langerhans cells increase in the dermal lesions of adult T cell leukaemia in Japan
}

\author{
M SHAMOTO \\ From the Department of Pathology, Fujita-Gakuen University School of Medicine, Toyoake, Aichi, Japan
}

SUMMARY In cases of adult $T$ cell leukaemia neoplastic $T$ cell infiltration in the skin was accompanied by an increase in Langerhans cells. This is in keeping with the view that Langerhans cells may induce antigen-specific and allogenic $T$ cell activation.

Langerhans cells were first discovered in the epidermis of the skin in $1868^{1}$; subsequently these cells were also found in the lymph nodes, ${ }^{2-4}$ thymus, ${ }^{5}$ and dermis. ${ }^{6}$ Langerhans cell granules have also been observed in histiocytic cells of histiocytosis $\mathrm{X}^{78}$ which thus appears to be a pathological condition of Langerhans cells. It is generally recognised that Langerhans cells belong to the mononuclear phagocyte system ${ }^{9}$ and function as antigen presenting cells. ${ }^{10}$ It is thought that Langerhans cells could stimulate $T$ lymphocytes, and this could be one of the reasons why Langerhans cells are markedly increased in the paracortical areas of dermatopathic lymphadenitis. ${ }^{23}$

Recently, immunological examinations have confirmed that Langerhans cells bear Fc-IgG, C3 receptors, ${ }^{11}$ express $\mathrm{Ia}^{12}$ and the monoclonal antibody, OKT6. ${ }^{13}$ Takahashi et al ${ }^{14}$ have proved that the monospecific antibody which is formed against nervous system specific $\mathrm{S}-100$ protein is positive in the interdigitating reticulum cells of the human lymph nodes, and S-100 protein is also positive in the epidermal Langerhans cells. ${ }^{15}$ Rausch et $a l^{3}$ have stressed a close relation between Langerhans and interdigitating reticulum cells. Morphologically and functionally, it is difficult to differentiate between these cells, except by the presence of granules in Langerhans cells.

Adult $T$ cell leukaemia in Japan is a specific $T$ cell leukaemia which frequently has skin involvement. ${ }^{16}$ In the dermis of adult $T$ cell leukaemia relatively large and clear cells often mingle with neoplastic cells with markedly convoluted nuclei. We have clarified that these clear cells are Langerhans cells by the peroxidase antiperoxidase (PAP) method using S-100 protein and by electron microscopy.

\section{Material and methods}

Ten skin biopsy specimens, the diagnosis of which was confirmed as adult $T$ cell leukaemia were examined. For light microscopy, tissues of the skin were fixed in buffered formalin and carefully embedded in paraffin in such a way that the temperature did not rise above $60^{\circ} \mathrm{C}$. The peroxidase antiperoxidase (PAP) method was used. Namely, paraffin sections were dewaxed and treated with $0.3 \% \mathrm{H}_{2} \mathrm{O}_{2}$ in methanol $(15 \mathrm{~min})$ to block endogenous peroxidase activity, and were then rinsed in $70 \%$ ethanol. After washing with

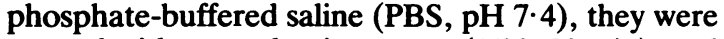
treated with normal swine serum $(1 / 20,30 \mathrm{~min})$, and then washed with PBS, and incubated with monospecific anti S-100 protein antibody $(20 \mu \mathrm{g} / \mathrm{ml})$ overnight at $4^{\circ} \mathrm{C}$. The sections were rinsed in PBS next day, and incubated with swine antirabbit IgG (Dako, 1/20, $30 \mathrm{~min}$ ). They were rinsed in PBS and incubated with rabbit antihorseradish peroxidase complex (PAP) (Dako, 1/50, $30 \mathrm{~min})$. After washing, an enzyme reaction was developed with a DAB- $\mathrm{H}_{2} \mathrm{O}_{2}$ solution according to Takahashi et al. ${ }^{14}$ Sections were counterstained with methyl green pyronin. Paraffin sections were also stained with haematoxylin and eosin for standard histological study.

Ultrastructurally, small pieces of the tissues were fixed in cold $2.5 \%$ glutaraldehyde and $2 \%$ paraformaldehyde buffered at $\mathrm{pH} 7.2$ with a $0.05 \mathrm{M}$ cacodylate buffer. They were then postfixed in $1 \%$ osmium tetroxide buffered with cacodylate. After dehydration in graded-series of ethanol, these were embedded in epoxy resin. Thin sections were cut with glass knives on an ultramicrotome, and stained with 


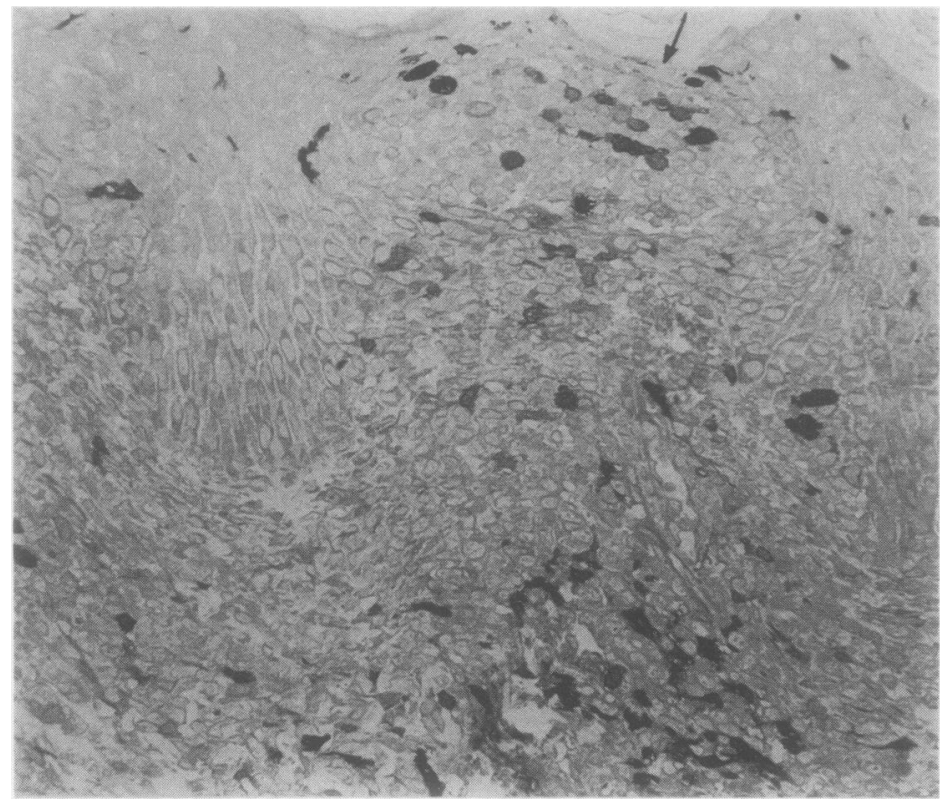

Fig. 1 There are a few $S-100$ Shamoto protein-positive cells in the epidermis, and many in a Pautrier's microabscess (arrow) and in the dermis. $\times 250$

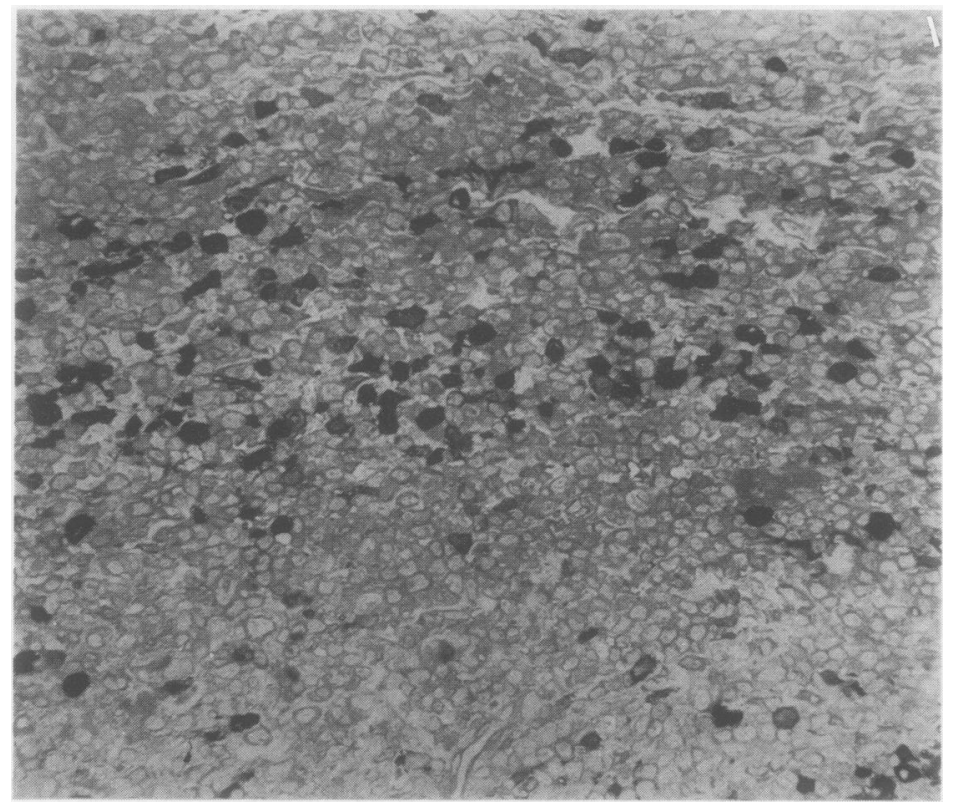

Fig. 2 Many $S-100$ protein-positive cells: mingle with leukaemic cells in the dermis. $\times 250$

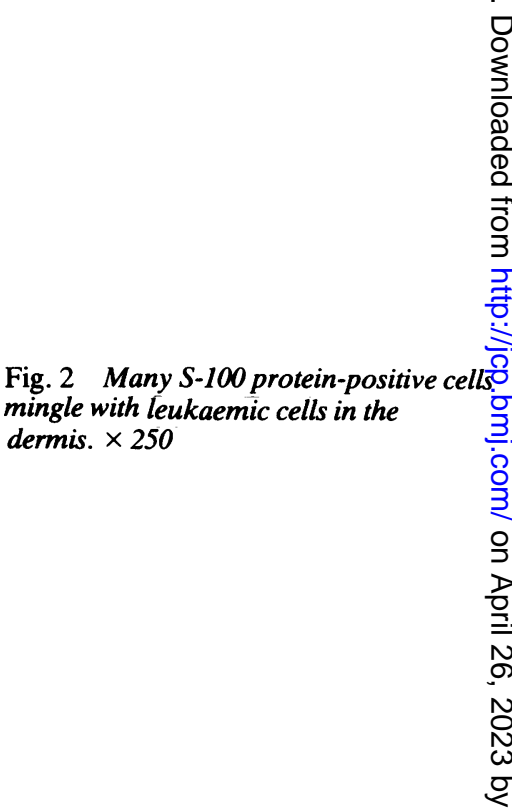

uranyl acetate and lead compounds, and examined on a Jeolco 100 CX electron microscope.

\section{Results}

Cells resembling Sézary cells and/or the small cell variant form of Sézary cells (Sézary-type cells) infiltrated the dermis, especially the upper dermis, although the extent and degree of the infiltration differed in each case. Pautrier's microabcesses werE also characteristic in adult $T$ cell leukaemia Relatively large cells with clear and broad cytoplasng and irregularly shaped nuclei mingled with Sézaryo type cells in the dermis. A few cells were positive for 


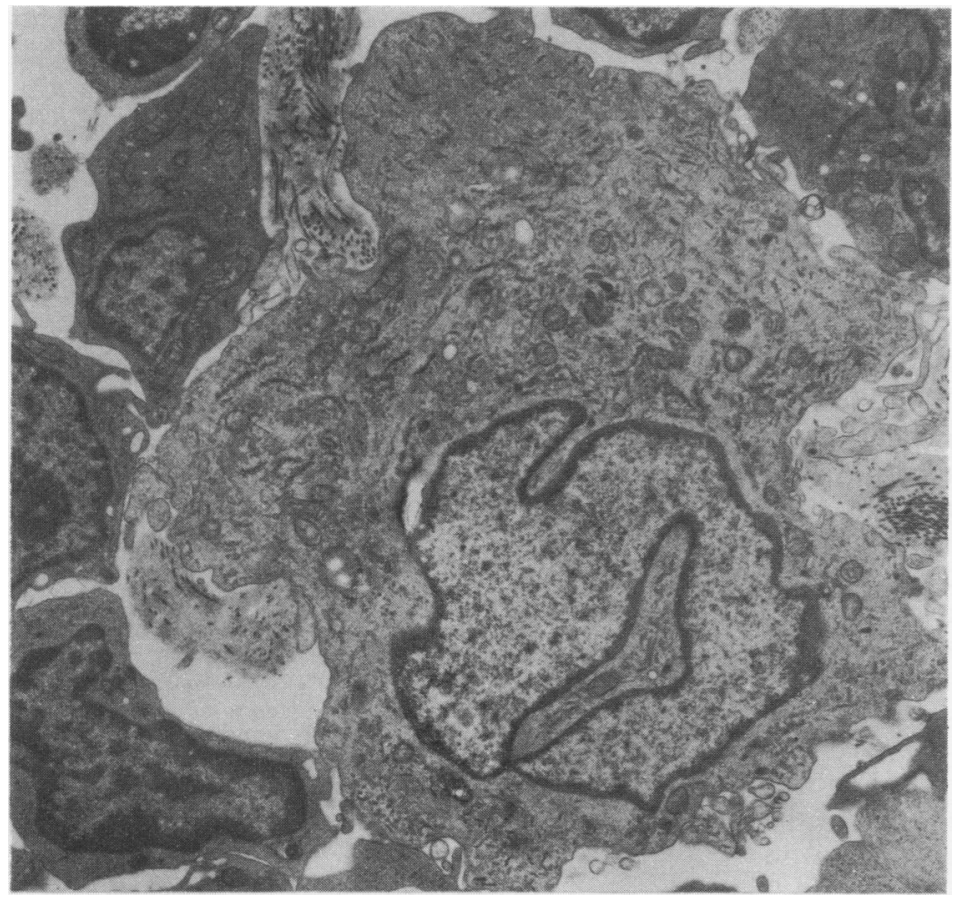

Fig. 3 A Langerhans cell is seen in the dermis. $\times 4800$

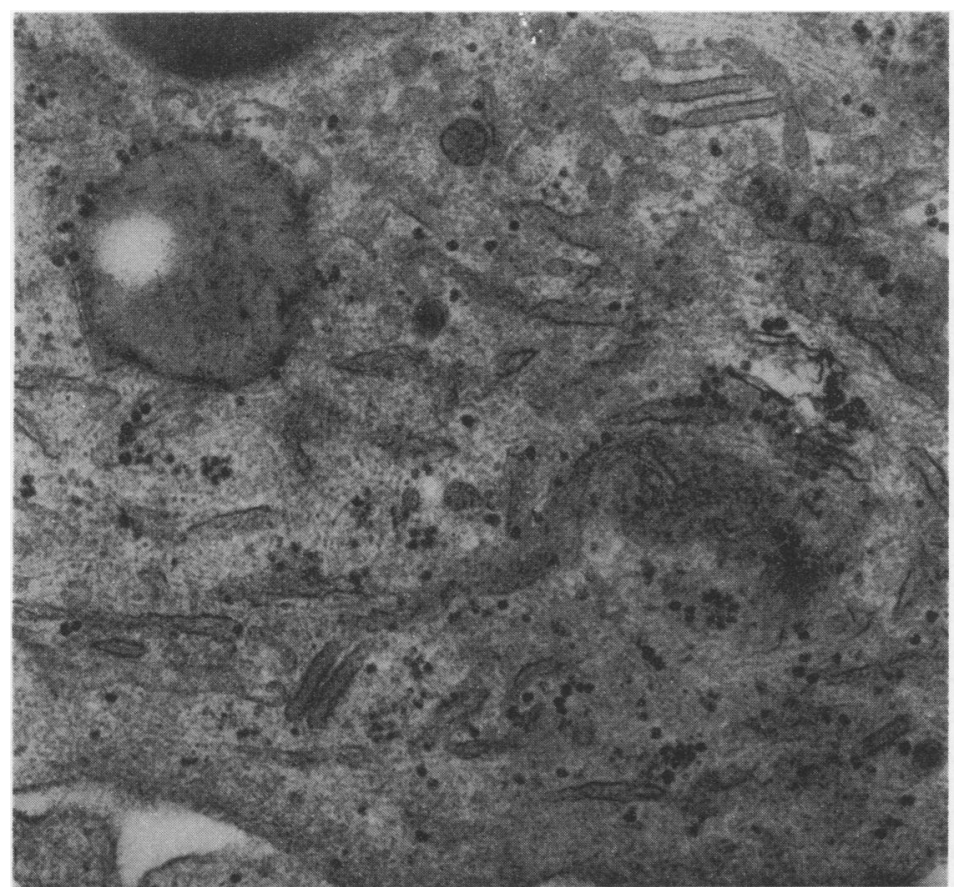

Fig. 4 Several Langerhans cell granules are found in the cytoplasm. $\times 48000$ 
S-100 protein in the epidermis (Fig. 1). However, the ratio of the appearance of the $\mathrm{S}-100$ protein positive cells was higher in the dermis than in the epidermis, although the number of the positive cells corresponded to that of the clear cells when stained with haematoxylin and eosin, but differed slightly according to case (Figs. 1 and 2). S-100 protein was devoid of the reaction products in some nuclei, and was positive only in the cytoplasm.

Ultrastructurally, a few Langerhans cells were observed in the epidermis, but in the dermis were often observed mixed with neoplastic cells (Fig. 3). The nuclei of the Langerhans cells were irregular in outline. The chromatin appeared finely dispersed. The broad cytoplasm contained Golgi apparatus, free ribosomes, and rough endoplasmic reticulum. Mitochondria were moderate in number. Filamentous structures were often found and Langerhans cell granules were characteristically observed in the cytoplasm (Fig. 4).

\section{Discussion}

In adult $T$ cell leukaemia in Japan, it is one of the characteristic features that neoplastic $T$ cells with markedly convoluted nuclei infiltrate the dermis. ${ }^{16}$ We have reported in an ultrastructural study ${ }^{17}$ that the greater part of the cells of adult $T$ cell leukaemia is very similar to the small cell variant form of Sézary syndrome. In the present study, we have shown by the PAP method and electron microscopy that Langerhans cells also increase in the dermal lesions. Langerhans cells normally comprise only $4-5 \%$ of the epidermal cells and are rarely found in the dermis. ${ }^{18}$ In adult $T$ cell leukaemia, an increase in the number of Langerhans cells was observed in the dermis, although not in the epidermis. Langerhans cells can be found in the lymph nodes of several other conditions. $^{2-4}$ In particular, an extreme enlargement of the paracortical, thymus-dependent areas which is due to a large number of interdigitating reticulum cells and Langerhans cells is the main morphological feature of dermatopathic lymphadenitis. ${ }^{23}$ It has been suggested that Langerhans cells may arrive in the paracortical areas of the lymph nodes from the skin, because Langerhans cells can be found in dermal lymphatics, in the marginal sinuses and in the small lymphatics of the lymph nodes. Langerhans cells and interdigitating reticulum cells closely connect with $\mathrm{T}$ lymphocytes in the lymph nodes. Stingl et al ${ }^{10}$ have suggested that Langerhans cells have a macrophage-like function as antigen-presenting cells and allogenic cells to $\mathrm{T}$ lymphocytes. The present evidence indicates a close relation between Langerhans cells and $\mathrm{T}$ lymphocytes. Loo et al ${ }^{19}$ have found C-type virus-like particles in the Langerhans cells of skin biopsies and lymph nodes from patients with mycosis fungoides and Sézary's syndrome. It hais been suggested that the aetiology of adult $T$ ce $\bar{T}$ leukaemia may be retrovirus particles with type $\vec{\sigma}$ morphology. ${ }^{20}$

The author wishes to acknowledge the advice give by Dr T Suchi, Chief, Department of Clinical Pathology, Aichi Cancer Center Hospital, and Prof Dr M Tajima, Department of Pathology, Fujita Gakuen University School of Medicine, and als $\vec{\theta}$ thanks to Dr T Nakajima, Pathology Division National Cancer Center Research Institute fợ preparing the anti-S-100 protein antibody.

\section{References}

Langerhans P. Über die Nerven der menschlichen Haut. Virchove Arch Pathol Anat Physiol 1968;44:325-37.

2 Jimbow K, Sato S, Kukita A. Cells containing Langerhan granules in human lymph nodes of dermatopath lymphadenitis. J Invest Dermatol 1969;53:295-9.

${ }^{3}$ Raush E, Kaiserling E, Goos M. Langerhans cells and, interdigitating reticulum cells in the thymus-dependent region in human dermatopathic lymphadenitis. Virchows Arch [C Pathol] 1977;25:327-43.

4 Shamoto M, Kaplan C, Katoh AK. Langerhans cell granules human hyperplastic lymph nodes. Arch Pathol 1971;92:46-52.

${ }^{5}$ Hoshino T, Kukita A, Sato S. Cells containing Birbeck granule (Langerhans cell granules) in the human thymus. $J$ Electrain Microsc 1970;19:271-6.

${ }^{6}$ Hashimoto K, Tarnowski WM. Some new aspects of the Langerhans cell. Arch Dermatol 1968;97:450-64.

${ }^{7}$ Basset F, Turiaf J. Identification par la microscopie électroniqự de particules de nature probablement vitale dans les lésions granulomateuses d'une histiocytose $\mathrm{X}$ pulmonaire. $C R$ Acad $S$ 1965;261:3701-3.

${ }^{8}$ Shamoto M. Langerhans cell granules in Letterer-Siwe disease: An electron microscopic study. Cancer 1970;26:1102-8.

9 Thorbecke GJ, Silberberg-Sinakin I, Flotte TJ. Langerhans celfs as macrophages in skin and lymphoid organs. $J$ Invest Dermat 1980;75:32-43.

${ }^{10}$ Stingl G, Katz SI, Green I, Shevach EM. The functional role of Langerhans cells. J Invest Dermatol 1980;74:315-8.

" Stingl G, Wolff-Schreiner EC, Pichler WJ, Gschnait F, Knapp Wo Epidermal Langerhans cells bear Fc and $\mathrm{C} 3$ receptors. Nature 1977;268:245-6.

${ }^{12}$ Klareskog L, Tjernlund UM, Forsum U, Peterson PA. Epiderma Langerhans cells express Ia antigens. Nature 1977;268:248-50. N

${ }^{13}$ Murphy GF, Bhan AK, Sato S, Mihm MC Jr, Harrist TJ. A new immunologic marker for human Langerhans cells. $N$ Engl $J$ Mad 1981;304:791-2.

14 Takahashi K, Yamaguchi H, Ishizeki J, Nakajima T, Nakazato X Immunohistochemical and immunoelectron microscopto localization of S-100 protein in the interdigitating reticulum celf of the human lymph node. Virchows Arch [Cell Pathot] 1981;37:125-35.

is Nakajima T, Watanabe S, Sato Y, Shimosato Y, Motoi $M^{\text {P }}$ Lennert K. S-100 protein in Langerhans cells, interdigitating reticulum cells and histiocytosis X cells. Gann 1982;73:429-320

${ }^{16}$ Uchiyama T, Yodoi J, Sagawa K, Takatsuki K, Uchino H. Adư⿱ T-cell leukemia: clinical and hematologic features of 16 caseff Blood 1977;50:481-92.

"Shamoto M, Murakami S, Zenke T. Adult T-cell leukemia ig Japan: An ultrastructural study. Cancer 1981;47:1804-11. 
18 Baer RL. Introductory remarks to the session on Langerhans cells. J Invest Dermatol 1980;74:307-8.

19 Loo van der EM, Muijen van GNP, Vloten van WA, Beens W, Scheffer E, Meijer CJLM. C-type virus-like particles specifically localized in Langerhans cells and related cells of skin and lymph nodes of patients with mycosis fungoides and Sezary's syndrome. A morphological and biochemical study. Virchows Arch [Cell Pathol] 1979;31:193-203.

${ }^{20}$ Hinuma Y, Nagata K, Hanaoka M, et al. Adult T-cell leukemia:
Antigen in an ATL cell line and detection of antibodies to the antigen in human sera. Proc Natl Acad Sci USA 1981;78:647680.

Requests for reprints to: Mikihiro Shamoto, Department of Pathology, Fujita-Gakuen University School of Medicine, Kutsukake-cho, Toyoake-city, Aichi-prefecture 470-11, Japan. 